\title{
PENGARUH KELENGKAPAN PRODUK DAN KUALITAS PELAYANAN TERHADAP KEPUTUSAN PEMBELIAN
}

(Studi Kasus Pada Swalayan Ada Baru Di Kota Salatiga)

\author{
Oleh \\ Tri Widodo \\ Dosen Tetap STIE AMA Salatiga
}

\begin{abstract}
Completeness of the product for a self-service meruapakan important factor to attract consumers. The more complete product offered more it will meet the desires and needs of consumers. In addition to a range of products, quality of service is also a key to the success of efforts to develop usahaanya sebauh. Thus providing good service becomes important. Completeness of product and service quality as a whole will be a consideration and will influence consumer purchase decisions in the purchase of products needed. So that the range of products and quality of service, had to be considered Supermarkets Adabaru in an effort to attract consumers and create a customer. This study design is the design of a survey conducted in order to test the effect of Completeness of product and service quality of the buying decision at Supermarket Adabaru Salatiga. Survey conducted on 96 respondents who are consumers Supermarkets Adabaru Salatiga.

Data analysis was performed using multiple linear regression. The results showed that: 1) Based on the questionnaire respondents Supermarkets Adabaru completeness of the product does not significantly influence the purchasing decision; 2) Quality of care significantly influence the purchasing decisions of consumers; 3) Completeness of product and service quality simultaneously significantly influence the purchasing decisions in Supermarkets Adabaru.
\end{abstract}

Keywords : Completeness of Product, Service Quality, Purchasing Decisions

\section{PENDAHULUAN}

Perkembangan bidang industri, jasa dan dagang sangat berperan penting dalam perkembangan perekonomian di suatu negara, perekonomian mampu memberikan perubahan-perubahan yang berarti bagi kehidupan masyarakat. Perubahan kondisi perekonomian Indonesia mengakibatkan semakin meningkatnya bisnis ritel atau eceran. Hal ini ditandai dengan semakin banyaknya bisnis ritel modern yang bermunculan, fenomena ini tidak hanya terjadi di kota-kota besar di Indonesia dengan konsep one stop shoping, yang menyediakan semua kebutuhan berbelanja di suatu tempat perbelanjaan (Ma'ruf, 2005:24) Ma'ruf (2005:24) mengemukakan, adanya globalisasi juga merupakan faktor utama terciptanya permintaan atau meningkatkan permintaan barang dan jasa ritel. 
Gaya hidup merupakan salah satu aspek kehidupan masyarakat yang dipengaruhi oleh faktor ini. Oleh karena itu, banyak peritel besar mengamati perkembangan globalisasi, khususnya perkembangan yang berpengaruh pada kehidupan masyarakat. Syarat yang harus di penuhi perusahaan agar sukses dalam persaingan adalah mencapai tujuan tersebut dengan mengimplementasikan pelayanan yang memuaskan dan mempertahankan pelanggan dengan menciptakan citra yang baik di hati konsumen yang nantinya akan menimbulkan loyalitas. Hal ini bisa dicapai oleh suatu perusahaan melalui upaya menghasilkan dan menyampaikan barang serta jasa yang diinginkan konsumen. Kegiatan tersebut sangat tergantung pada perusahaan atau sebagai atribut dalam kelengkapan produk seperti harga, produk, pelayanan umum, lokasi dan perilaku konsumen dalam proses pengambilan keputusan untuk membeli (Engel \& Paul, 2001:251).

Raharjani (2005:6), berpendapat bahwa konsumen cenderung memilih tempat yang menawarkan produk yang bervariasi dan lengkap menyangkut kedalaman, luas, dan kualitas keragaman barang yang ditawarkan oleh penjual. Ketersediaan barang dalam suatu pasar swalayan meliputi variasi merk yang banyak, tipe dan ukuran kemasan barang yang dijual, macam-macam rasa dari suatu produk yang akan dibeli. Bagi sebuah pasar swalayan kelengkapan barang dagangan merupakan faktor yang penting untuk menarik konsumen. Meskipun harga jual lebih tinggi dari pasar swalayan lainnya, tetapi karena lengkapnya barang yang dijual maka, pasar swalayan ini banyak menarik para pengunjung. Semakin lengkap sebuah pasar swalayan maka semakin memenuhi kebutuhan dan keinginan konsumen, sehingga konsumen akan memutuskan untuk melakukan pembelian produk mereka.

Kualitas layanan yang baik akan menciptakan kepuasan pelanggan. Sehingga kualitas layanan yang baik serta kepuasan pelanggan tersebut dapat mempengaruhi intensitas kunjungan pelanggan pada kesempatan berikutnya pada badan usaha yang bersangkutan. Kualitas layanan adalah permulaan dari kepuasan pelanggan. Pelanggan dalam menentukan kualitas layanan tidak hanya berdasarkan pada hasil dari suatu layanan tersebut tetapi juga memperhatikan proses pemberian layanan tersebut. Service quality is the customer perception of the superiority of the service (Zeithaml, Berry \& Parasuraman dkk 2004). Hal ini berarti bahwa kualitas layanan sangat dipengaruhi oleh persepsi pelanggan, oleh karena itu perusahaan harus berusaha untuk 
memberikan layanan yang terbaik agar dapat memenuhi atau bahkan mampu melampaui kebutuhan pelanggan agar tercapai kepuasan.

Keputusan pembelian merupakan usaha konsumen untuk mengidentifikasikan semua pilihan yang mungkin untuk memecahkan persoalan itu dan menilai pilihanpilihan secara sistematis dan objektif serta sasaran-sasarannya yang menentukan keuntungan serta kerugiannya masing-masing. Swalayan Ada Baru merupakan salah satu swalayan di kota Salatiga, yang kehadirannya dapat memberikan kemudahan bagi masyarakat untuk memperoleh barang-barang yang di tawarkan. Swalayan Ada Baru di Kota Salatiga menjual kebutuhan rumah tangga, pakaian, perlengkapan kantor, perlengkapan olah raga serta swalayan Ada Baru memiliki perlengkapan hiburan yang semakin meningkatkan pemasarannya. Kehadiran swalayan Ada Baru merupakan tuntutan perubahan gaya hidup masyarakat, di mana swalayan Ada Baru merupakan salah satu pusat perbelanjaan di Kota Salatiga.

\section{Persoalan Penelitian}

Persoalan dalam penelitian ini adalah :

1. Apakah kelengkapan produk berpengaruh terhadap keputusan pembelian di Swalayan Ada Baru kota Salatiga?

2. Apakah kualitas pelayanan berpengaruh terhadap keputusan pembelian di Swalayan Ada Baru Kota Salatiga?

3. Apakah kelengkapan produk dan kualitas pelayanan berpengaruh terhadap keputusan pembelian di Swalayan Ada Baru secara simultan?

\section{Tujuan dan Manfaat Penelitian}

Tujuan penelitian ini antara lain:

1. Untuk mengetahui pengaruh kelengkapan produk terhadap keputusan pembelian di Swalayan Ada Baru kota Salatiga.

2. Untuk mengetahui pengaruh kualitas pelayanan terhadap keputusan pembelian di Swalayan Ada Baru kota Salatiga.

3. Untuk mengetahui pengaruh kelengkapan produk dan kualitas pelayanan terhadap keputusan pembelian di Swalayan Ada Baru secara simultan.

Penelitian ini diharapkan akan memberi manfaat baik peneliti, praktisi, maupun akademisi. Adapun manfaat yang diharapkan penelitian ini bagi peneliti untuk dapat lebih memperdalam ilmu pemasaran dan perilaku konsumen, 
khususnya faktor-faktor yang menjadi penentu dalam keputusan pembelian konsumen dalam melakukan pembelian. Bagi praktisi penelitian ini diharapkan dapat memberikan sumbangan informasi dan pemikiran bagi praktisi (pemasar) untuk menjadi bahan pertimbangan bagaimana seharusnya mempelajari perilaku pembelian yang dilakukan konsumen. Bagi akademisi hasil penelitian yang didapatkan nanti diharapkan dapat berguna sebagai bahan pertimbangan bagi penelitian selanjutnya, terutama untuk penelitian yang berkaitan dengan faktorfaktor yang menjadi pendorong konsumen untuk menentukan dan memutuskan dalam pembelian produk.

\section{LANDASAN TEORI}

\section{Keputusan Pembelian}

Schiffman dan Kanuk (2008:485) mendefinisikan keputusan merupakan seleksi terhadap dua pilihan alternatif atau lebih, dengan perkataan lain, pilihan alternatif harus tersedia bagi seseorang ketika mengambil keputusan. Sebaliknya, jika konsumen tersebut tidak mempunyai alternatif untuk memilih dan benar-benar terpaksa melakukan pembelian tertentu dan tindakan tertentu, maka keadaan tersebut bukan merupakan suatu keputusan. Peter dan Olson (2005:162), mengemukakan keputusan pembelian adalah proses pengintegrasian yang mengkombinasikan pengetahuan untuk mengevaluasi dua atau lebih perilaku alternatif dan memilih salah satu diantaranya. Dari dua pengertian tersebut, ditarik kesimpulan bahwa keputusan merupakan suatu eksekusi atas seleksi ketika seseorang dihadapkan pada minimal dua pilihan dengan melibatkan aspek kognisi, perhatian, pemahaman, serta proses penerjemahan informasi.

Untuk meraih keberhasilan, pemasar harus melihat lebih jauh bermacam faktor yang mempengaruhi pembeli dan mengembangkan pemahaman mengenai bagaimana konsumen melakukan keputusan pembelian (Kotler, 2002:201). Secara khusus, pemasar harus mengidentifikasi siapa yang membuat keputusan pembelian. Pemasar membedakan lima peran yang dimainkan dalam keputusan pembelian (Simamora, 2004:15) antara lain : Pencetus, Pemberi pengaruh, Pengambil keputusan, Pembeli, dan Pemakai.

Adapun jenis-jenis pengambilan keputusan, yaitu (Peter dan Olson, 2005:178): 
1). Pengambilan Keputusan Ekstensif; Pengambilan keputusan ekstensif biasanya melibatkan sejumlah besar perilaku pencarian yang dibutuhkan untuk mengidentifikasi alternatif pilihan dan mencari kriteria pilihan yang akan digunakan untuk mengevaluasi.

2). Pengambilan Keputusan Terbatas; Pengambilan keputusan terbatas tidak banyak melibatkan upaya pencarian informasi.

3). Perilaku Pilihan Rutin; Perilaku pilihan rutin membutuhkan sangat sedikit kapasitas kognitif atau kontrol sadar.

Dalam beberapa situasi, konsumen mungkin mencari informasi tambahan dan dalam situasi lain mereka hanya meninjau kembali apa yang sudah mereka ketahui (Schiffman dan Kanuk, 2008:487). Rangsangan pemasaran untuk pembelian produk terdiri dari $4 \mathrm{P}$ untuk prosuk fisik dan $7 \mathrm{P}$ untuk produk jasa, yaitu: produk, harga, tempat, promosi, orang, proses dan bukti fisik. Rangsangan lain adalah kekuatan-kekuatan utama dalam lingkungan, yaitu: ekonomi, teknologi, politik dan budaya. Rangsanganrangsangan ini mempengaruhi pembeli dan berubah menjadi tanggapan pembeli untuk memutuskan pilihan produk atau jasa, merek, toko, waktu dan jumlah yang juga akan dijadikan indikator dalam keputusan pembelian.

Proses keputusan pembelian konsumen yang dikemukakan Kotler (2002:204) terdiri dari lima tahap yang dilakukan oleh seorang konsumen sebelum sampai pada keputusan pembelian dan selanjutnya pasca pembelian. Hal ini menunjukkan bahwa proses membeli yang dilakukan oleh konsumen dimulai jauh sebelum tindakan membeli dilakukan serta mempunyai konsekuensi setelah pembelian tersebut dilakukan. Kelima tahapan tersebut dapat di lihat pada gambar berikut.

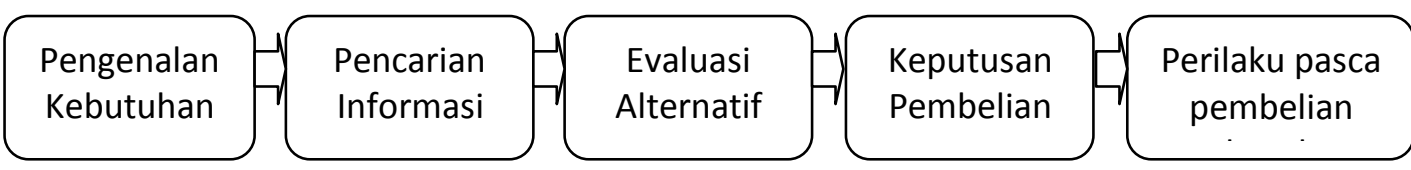

Gambar 1 Model Lima Tahap Proses Pembelian

(Sumber: Kotler, 2002:204)

Tahapan-tahapan tersebut adalah sebagai berikut:

1. Pengenalan Kebutuhan 
Kotler (2002:204) mengemukakan bahwa proses pembelian dimulai saat pembeli mengenali sebuah masalah atau kebutuhan. Kebutuhan tersebut dapat dicetuskan oleh rangsangan internal atau eksternal. Pemasar perlu mengidentifikasi keadaan yang memicu kebutuhan tertentu.

2. Pencarian Informasi

Kotler (2002:205) konsumen yang tergugah kebutuhannya akan terdorong untuk mencari informasi yang lebih banyak. Sumber informasi konsumen digolongkan ke dalam empat kelompok: (1) sumber pribadi; keluarga, teman, tetangga, kenalan, (2) sumber komersial; iklan, wiraniaga, penyalur, kemasan, pajangan di toko, (3) sumber publik; media massa, organisasi penentu peringkat konsumen, dan (4) sumber pengalaman; penanganan, pengkajian dan pemakaian produk.

\section{Evaluasi Alternatif}

Dalam tahap evaluasi, konsumen membentuk preferensi atas merek-merek dalam kumpulan pilihan. Konsumen juga mungkin membentuk niat untuk membeli produk yang paling disukai (Kotler, 2002:207).

4. Keputusan Pembelian

Dalam melaksanakan niat pembelian, konsumen dapat membuat lima sub keputusan pembelian, yaitu keputusan merek, keputusan pemasok, keputusan kuantitas, keputusan waktu, dan keputusan metode pembayaran (Kotler, 2002:208). Swastha dan Irawan (2001:118) mengemukakan ketika konsumen memutuskan untuk membeli, maka konsumen akan menghadapi serangkaian keputusan yang harus diambil yaitu: jenis produk, bentuk produk, merek, tempat (penjual), jumlah produk, waktu membeli, dan cara pembayarannya.

5. Perilaku Pasca Pembelian

Setelah membeli produk, konsumen akan mengalami level kepuasan atau ketidakpuasan tertentu. Tugas pemasar tidak berakhir saat produk dibeli, melainkan berlanjut hingga periode pasca pembelian.

a) Kepuasan Pasca Pembelian

Kepuasan pembeli merupakan fungsi dari seberapa dekat harapan pembeli atas suatu produk dengan kinerja yang dirasakan pembeli atas produk tersebut. Konsumen membentuk harapan mereka berdasarkan pesan yang 
diterima dari penjual, teman, dan sumber-sumber informasi lain. Jika kinerja produk lebih rendah dari harapan, pelanggan akan kecewa; jika ternyata sesuai harapan, pelanggan akan puas; jika melebihi harapan, pembeli akan sangat puas (Kotler, 2002:209).

b) Tindakan Pasca Pembelian

Kepuasan atau ketidakpuasan konsumen akan mempengaruhi perilaku selanjutnya. Jika konsumen puas, maka ia akan memperlihatkan kemungkinan yang lebih tinggi untuk membeli produk tersebut (Setiadi, 2003:19). Konsumen yang tidak puas akan mengambil satu atau dua tindakan. Pertama, mereka akan mengurangi ketidak cocokannya dengan meninggalkan atau mengembalikan produk tersebut. Kedua, mereka mengambil tindakan publik seperti mengajukan keluhan ke perusahaan, pergi ke pengacara, atau mengadu ke kelompok-kelompok lain (seperti lembaga-lembaga bisnis, swasta, atau pemerintah).

\section{Kelengkapan Produk}

Kotler (2002:448) menyatakan produk adalah segala sesuatu yang dapat ditawarkan ke suatu pasar untuk memenuhi kebutuhan atau keinginan. Konsumen akan melihat suatu produk berdasarkan pada karakteristik atau ciri, atau atribut produk dari produk tersebut. Gilbert (2003:113), "The product is the totality of the offer which will normally include the services, store layout, merchandise. It will also include the company, and product brand name", dapat disimpulkan bahwa produk adalah keseluruhan dari penawaran yang dilakukan secara normal oleh perusahaan kepada konsumen dalam memberikan layanan, letak toko, dan nama barang dagangannya. Konsumen akan memberikan kesan yang baik terhadap suatu toko apabila toko tersebut dapat menyediakan barang yang dibutuhkan dan diinginkan oleh konsumen. Oleh karena itu pengecer harus tanggap terhadap kebutuhan dan keinginan konsumen.

Faktor-faktor yang dipertimbangkan oleh suatu toko dalam memilih produk yang dijualnya yaitu (Gilbert, 2003:113):

1). Variety, kelengkapan produk yang di jual dapat mempengaruhi pertimbangan konsumen dalam memilih suatu toko. 
2). Width or Breath, tersedianya produk-produk pelengkap dari produk utama yang ditawarkan. Contohnya pada toko roti selain menyediakan roti juga menyediakan berbagai macam minuman.

3). Depth, merupakan macam dan jenis karakteristik dari suatu produk.

4). Consistency, produk yang sudah sesuai dengan keinginan konsumen harus tetap dijaga keberadaannya dengan cara menjaga kelengkapan, kualitas dan harga dari produk yang dijual.

5). Balance, berkaitan erat dengan usaha untuk menyesuaikan jenis dan macammacam.

Produk di beli oleh konsumen karena dapat memenuhi kebutuhan tertentu atau memberi manfaat tertentu, karakteristik produk tidak hanya meliputi aspek fisik produk (tangible features), tetapi juga aspek non fisik (intangible features) seperti citra dan jasa yang dapat di lihat. Dalam hal ini kelengkapan produk dapat di lihat dari kategori produk yang tersedia di suatu perusahaan retail atau swalayan, di mana pemasar membagi produk berdasarkan proses pembelian dan penggunaannya, menjadi produk konsumsi dan produk industri.

1. Produk Konsumsi (Consumption product) : Produk konsumsi merupakan barang atau jasa yang dikonsumsikan oleh rumah tangga atau individual. Produk yang dibeli konsumen akan langsung dikonsumsi sendiri. Produk itu tidak akan digunakan sebagai bahan baku produksi barang lain atau dijual kembali. Berdasarkan perilaku pembelian konsumen, produk konsumen di golongkan menjadi (Kismono, 2001:327) :

a. Convenience goods Adalah barang dan jasa yang harganya relatif tidak mahal, frekuensi pembeliannya tinggi, dan konsumen mengeluarkan sedikit usaha maupun pertimbangan sebelum membuat keputusan pembelian.

b. Shopping goods Adalah barang-barang dalam proses pemilihan dan pembelian di bandingkan oleh konsumen diantara berbagai alternatif yang tersedia. Contohnya alat-alat rumah tangga, pakaian, furniture, mobil bekas dll.

c. Special goods Adalah barang barang yang memiliki karekteristik atau identifikasi merek unik dimana sekelompok konsumen bersedia melakukan 
usaha khusus untuk membelinya misalnya mobil lamborchini, pakaian rancangan orang terkenal.

d. Unsought goods Adalah merupakan barang-barang yang tidak di ketahui konsumen atau kalaupun sudah di ketahui, tetapi pada umumnya belum terpikirkan untuk membelinya. Contohnya asuransi jiwa, ensiklopedia, tanah kuburan dan sebagainya.

2. Produk industry Produk industri adalah produk yang di pakai perusahaan untuk operasional menghasilkan barang atau jasa. Produk industry dapat di bagi menjadi beberapa kategori seperti produk instalasi, peralatan rumah tangga, persediaan, pelayanan, bahan mentah, komponen dan lain-lain (Kismono, 2001:328).

\section{Pelayanan}

Pasar merupakan suatu usaha untuk memenuhi kebutuhan dengan memberikan kualitas pelayanan yang sebaik mungkin terhadap apa yang diperlukan pelanggan, dengan adanya kualitas pelayanan yang baik, maka pelanggan akan memperoleh barang dan jasa untuk memenuhi kebutuhannya (Mowen dan Minor, 2002:89). Kualitas pelayanan yang baik sangat penting dalam usaha swalayan sehingga pelanggan akan menyukai pelayanan yang diberikan oleh pasar swalayan tersebut dan pada akhirnya pelanggan akan datang kembali untuk melakukan pembelian ulang.

Mowen dan Minor (2002:90) mengemukakan bahwa kualitas produk ataupun layanan merupakan suatu proses evaluasi menyeluruh pelanggan mengenai kebaikan kinerja barang atau jasa. Kualitas pelayanan berkaitan erat dengan kemampuan sebuah organisasi untuk memenuhi atau melebihi harapan pelanggan. Payne (2006:273) mengemukakan ukuran kualitas jasa adalah harapan yang dipersepsikan dibandingkan dengan kualitas jasa yang didapatkan. Selama ini ada pendapat bahwa kualitas jasa memiliki dua komponen penting yaitu, kualitas teknis yang merupakan hasil proses operasi jasa dan kualitas fungsional yang merupakan dimensi proses dalam hal interaksi antara pelanggan dengan penyedia jasa. Hal ini juga dijelaskan dalam buku Lupiyadi (2001:148) bahwa SERVQUAL dibangun atas adanya perbandingan dua faktor utama yaitu persepsi 
pelanggan atas 24 layanan yang nyata mereka terima (perceived service) dengan layanan yang sesungguhnya diharapkan (expected service).

Dari uraian diatas dapat disimpulkan bahwa kualitas layanan adalah Perbandingan antara harapan pelanggan tentang segala keunggulan ataupun keistimewaan dari jasa dengan apa yang telah diterima oleh pelanggan. Dalam perkembangan selanjutnya, yaitu pada tahun 1988, Parasuraman, dan kawankawan (dalam Tjiptono, 2001:67) menemukan bahwa sepuluh dimensi yang ada dapat dirangkum menjadi lima dimensi pokok. Kelima dimensi pokok tersebut meliputi:

1). Tangibles atau bukti fisik. Yaitu kemampuan suatu perusahaan dalam menunjukkan eksistensinya kepada pihak eksternal. Penampilan dan kemampuan sarana dan prasarana fisik perusahaan serta keadaan lingkungan sekitarnya adalah bukti nyata dari pelayanan yang diberikan oleh pemberi jasa.

2). Reliability atau keandalan. Yaitu kemampuan perusahaan untuk memberikan pelayanan sesuai yang dijanjikan secara akurat dan terpercaya. Kinerja harus sesuai dengan harapan pelanggan yang berarti ketepatan waktu, pelayanan yang sama untuk semua pelanggan tanpa kesalahan, sikap yang simpatik, dan dengan akurasi yang tinggi.

3). Responsiveness atau ketanggapan. Yaitu suatu kemauan untuk membantu dan memberikan pelayanan yang cepat dan tepat kepada pelanggan dengan penyampaian informasi yang jelas.

4). Assurance atau jaminan dan kepastian. Yaitu pengetahuan, kesopansantunan, dan kemampuan para pegawai perusahaan. Untuk menumbuhkan rasa percaya para pelanggan kepada perusahaan. Terdiri dari beberapa komponen yaitu komunikasi, kredibilitas, keamanan, kompetensi dan sopansantun.

5). Empathy Yaitu memberikan perhatian yang tulus dan bersifat individual atau pribadi yang diberikan kepada para pelanggan dengan berupaya memahami keinginan konsumen.

Rismiati \& Suratno (2001:278) mengemukakan terdapat lima penentu kualitas pelayanan, yaitu:

1). Keandalan, kemampuan untuk membuktikan janji pelayanan secara akurat. 
2). Responsif, kemauan untuk membantu konsumen dan menyediakan pelayanan yang sesuai.

3). Keyakinan, pengetahuan dan kepercayaan diri karyawan untuk membangun kepercayaan dari konsumen.

4).Empati, perhatian dan atensi pribadi kepada konsumen.

5). Bukti nyata, dari fasilitas fisik, peralatan, manusia dan materi komunikasi.

Pelayanan sangat berhubungan dengan perilaku konsumen dalam memutuskan apakah akan membeli produk tersebut atau tidak. Pelayanan yang baik dan berkualitas merupakan bagian dari penilaian konsumen terhadap variabel penjualan. Pelayanan yang baik meliputi kecepatan dalam melayani, keramahan petugas yang melakukan penjualan, kemudahan dalam melakukan transaksi perdagangan dan lain sebagainya (Rismiati \& Suratno, 2001:278).

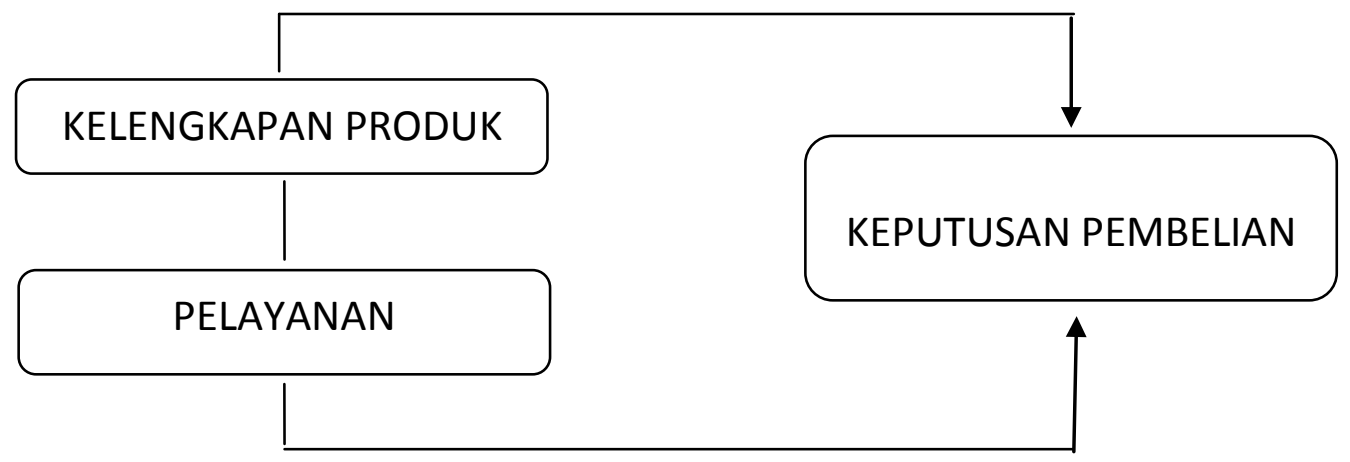

Gambar 2

Skema Rerangka Pemikiran

\section{METODE PENELITIAN}

\section{Jenis dan Desain Penelitian}

Jenis Penelitian ini adalah Deskriptif Korelasional yang mengungkapkan secara fakta sejauh mana hubungan variabel kelengkapan produk dan pelayanan sebagai variabel bebas (X) dan keputusan pembelian sebagai variabel terikat (Y). Adapun pendekatan yang digunakan dalam penelitian ini adalah pendekatan kuantitatif. Berdasarkan rumusan masalah dan hipotesis penelitian, penelitian ini terdiri dari dua variabel yang meliputi variable bebas kelengkapan produk (X1), kualitas pelayanan (X2) dan variabel terikat yaitu keputusan konsumen (Y). Teknik ini menggunakan teknik analisis regresi berganda, di mana teknik 
tersebut akan menguji hipotesis yang menyatakan adanya pengaruh antara variabel bebas dan variable terikat. Seperti pernyataan Suharsimi (2006:296) bahwa analisis regresi berganda adalah analisis tentang hubungan antara satu dependen variabel dengan atau lebih independen varibel

\section{Populasi dan Sampel}

Populasi adalah keseluruhan objek penelitian sedangkan sampel adalah bagian dari jumlah dan karakteristik yang dimiliki oleh populasi tersebut, (Sugiyono, 2004:73). Sampel merupakan bagian atau subset dari pada populasi, sampel diambil dari bagian populasi yang dipilih. Metode pengambilan sampel yang digunakan dalam penelitian ini adalah dengan metode non probability sampling, karena populasi yang diteliti infinite (populasi yang jumlah dan identitas anggota populasi tidak diketahui) selain itu juga dilakukan pengambilan sampel secara accidental Sampling (Convenience sampling). Menurut Santoso dan Tjiptono (2001:89-90) accidental Sampling (Convenience sampling) adalah prosedur sampling yang memilih sampel dari orang atau unit yang paling mudah dijumpai atau diakses. Sedangkan menurut Sugiyono (2004:77) accidental Sampling adalah mengambil responden sebagai sampel berdasarkan kebetulan, yaitu siapa saja yang secara kebetulan bertemu dengan peneliti dapat digunakan sebagai sampel bila orang yang kebetulan ditemui cocok sebagai sumber data dengan kriteria utamanya adalah orang tersebut merupakan konsumen atau pembeli (user) dari Swalayan Ada Baru Salatiga, dengan kriteria pendidikan minimal SLTA dan sudah berkeluarga, lebih diutamakan ibu rumah tangga. Sampel yang diambil sebanyak 96,04 orang. Untuk memudahkan perhitungan maka dibulatkan menjadi 96 orang.

\section{Data dan Metode Pengumpulan Data}

Metode pengumpulan data dimaksudkan untuk memperoleh informasi yang relevan, akurat dan reliabel. Metode yang di gunakan antara lain:

a. Observasi (pengamatan); teknik pengumpulan data dengan cara mengamati secara langsung produk yang menjadi obyek penelitian.

b. Metode Wawancara; digunakan sebagai teknik pengumpulan data, apabila peneliti ingin melakukan studi pendahuluan untuk menemukan permasalahan yang harus diteliti, dan juga apabila peneliti ingin mengetahui hal-hal dari 
responden yang lebih mendalam dan jumlah respondennya kecil (Sugiyono, 2009:130).

c. Metode angket (kuesioner); kuesioner yaitu teknik pengumpulan data yang dilakukan dengan cara memberi seperangkat pertanyaan atau pernyataan tertulis kepada responden untuk dijawab oleh responden (Sugiyono, 2009:135).

\section{Teknik Analisis Data}

\section{Analisis Regresi Berganda}

Analisis regresi berganda ini adalah analisis tentang hubungan antara satu dependent variable dengan dua atau lebih independent variable (Suharsimi, 2006:265). Analisis regresi berganda dapat dirumuskan sebagai berikut:

$$
\mathrm{Y}=\mathrm{a}+\mathrm{b}_{1} \mathrm{X}_{1}+\mathrm{b}_{2} \mathrm{X}_{2}+\mathrm{e}
$$

Keterangan:

$\mathrm{Y}=$ variabel terikat yaitu proses keputusan pembelian

$\mathrm{a}=$ konstanta

$\mathrm{b}=$ koefisien regresi variabel bebas

$\mathrm{X} 1$ = kelengkapan produk

$\mathrm{X} 2$ = pelayanan

$\mathrm{e}=$ standar error

\section{Uji Hipotesis}

a. Uji t

Dalam penelitian ini dilakukan uji-t yang fungsinya adalah untuk mengetahui pengaruh secara parsial antara variabel bebas $(\mathrm{X} 1, \mathrm{X} 2$,) dengan variabel terikat $(\mathrm{Y})$.

Kriteria untuk penolakan dan penerimaan hipotesis adalah:

1) Nilai thitung < ttabel, maka Hipotesis nol (Ho) diterima dan hipotesis alternatif (Ha) ditolak 
2) Nilai thitung > ttabel, maka Hipotesis nol (Ho) ditolak dan hipotesis alternatif (Ha) diterima

Atau dengan melihat signifikansi, yaitu:

1) Signifikansi $\mathrm{t} \leq 0,05$ maka hipotesis nol (Ho) akan ditolak dan Hipotesis alternatif (Ha) diterima

2) Signifikansi $t>0,05$ maka hipotesis nol (Ho) akan diterima dan Hipotesis alternatif (Ha) ditolak.

b. Uji F

Uji F pada dasarnya menunjukkan apakah semua variabel bebas yang dimasukkan dalam model mempunyai pengaruh secara simultan terhadap variabel terikat.

Kriteria untuk penolakan dan penerimaan hipotesis adalah:

1) Nilai Fhitung $<$ Ftabel, maka Hipotesis nol (Ho) diterima dan hipotesis alternatif (Ha) ditolak

2) Nilai Fhitung> Ftabel, maka Hipotesis nol (Ho) ditolak dan hipotesis alternatif (Ha) diterima

Atau dengan melihat signifikansi, yaitu:

1) Signifikansi $F \leq 0,05$ maka hipotesis nol (Ho) akan ditolak dan Hipotesis alternatif (Ha) diterima

2) Signifikansi F > 0,05 maka hipotesis nol (Ho) akan diterima dan Hipotesis alternatif (Ha) ditolak

\section{HASIL PENELITIAN DAN PEMBAHASAN}

\section{Karakteristik Responden}

Dalam penelitian ini, kuesioner dibagikan kepada 96 responden. Setelah melalui analisis data, semua data memenuhi untuk dianalisis lebih lanjut. Adapun karakteristik responden berdasarkan jenis kelamin responden pria berjumlah 18 orang $(18,75 \%)$ dan responden wanita berjumlah 78 orang $(81,25 \%)$. Sementara, berdasarkan usia, dari 96 data terkumpul sebanyak 21 responden yang berusia 41-46 tahun (21,9\%), usia 35-40 tahun sebanyak 17 responden (17,7\%), usia 29-34 tahun sebanyak 15 responden (15,6\%), usia 5358 tahun 13 responden (13,5\%), usia 23-28 dan usia 47-52 tahun masing- 
masing sebanyak 10 responden (10,4\%), usia 59-64 tahun sebanyak 6 responden $(6,3 \%)$, dan usia $17-22$ sebanyak 4 responden $(4,2 \%)$.

Terakhir karakteristik responden berdasarkan pekerjaan, sebanyak 46 responden berprofesi sebagai Ibu Rumah Tangga (47,9\%), 34 responden berprofesi sebagai pekerja (swasta) (35.4\%), dan 16 orang berprofesi sebagai PNS $(16,7 \%)$.

\section{Uji Asumsi Klasik}

\section{a. Uji normalitas data}

Uji normalitas bertujuan untuk menguji apakah dalam model regresi, variable pengganggu atau residual memiliki distribusi normal. Model regresi yang baik adalah distribusi normal atau mendekati normal. Jika data 5 menyebar di sekitar garis diagonal dan mengikuti arah garis diagonal atau grafik histogramnya menunjukkan pola distribusi normal, maka model regresi memenuhi asumi normalitas, dan sebaliknya maka model regresi tidak memenuhi asumsi normalitas (Ghozali, 2006:112). Hasil pengujian normalitas data dengan menggunakan grafik P-P Plot dapat dilihat pada gambar berikut :

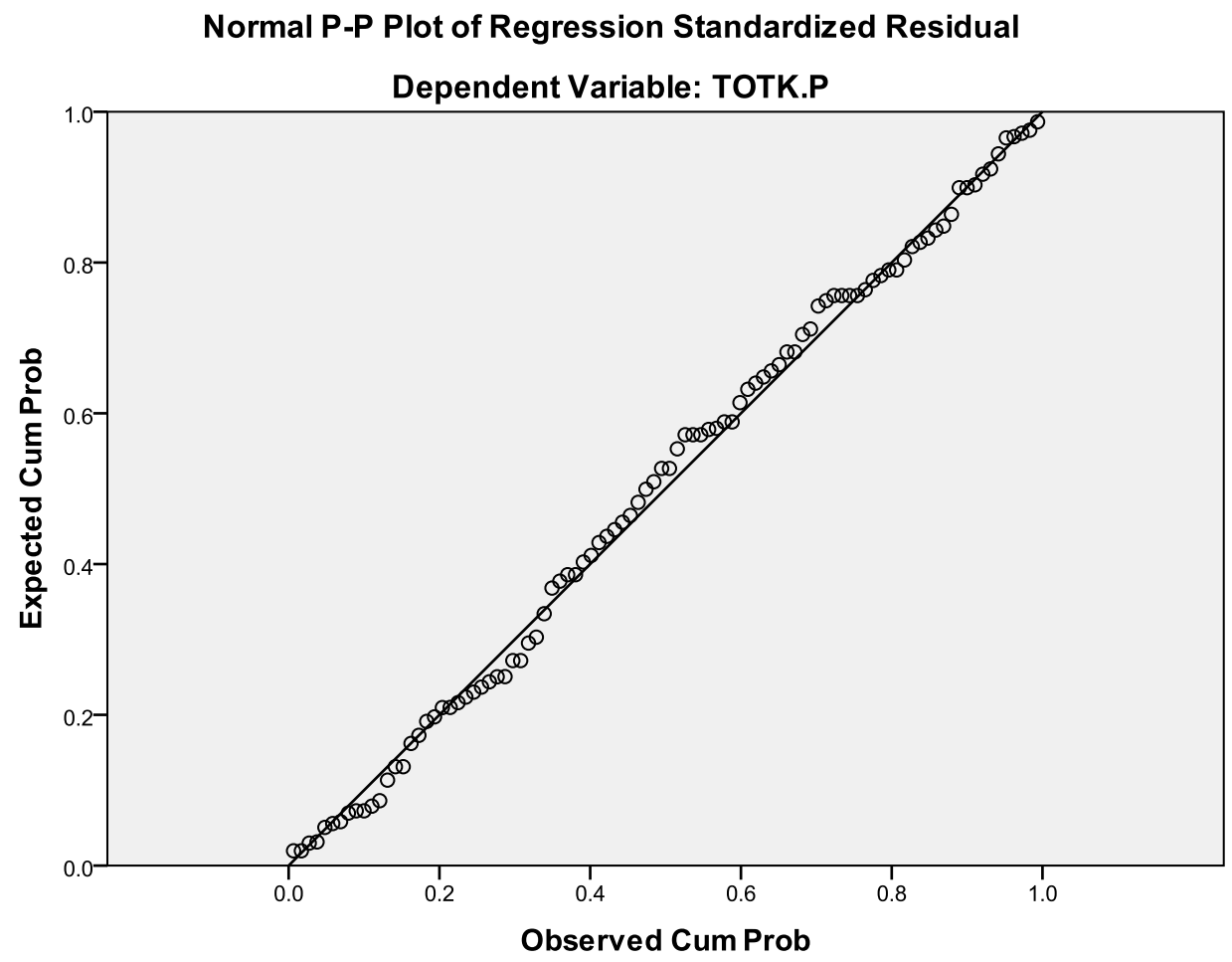

Gambar 2. Uji Normalitas data 
Dari gambar 2 diatas dapat disimpulkan bahwa model regresi layak untuk dipakai.

\section{b. Uji multikolinearitas}

Uji multikolinieritas bertujuan untuk menguji apakah model regresi ditemukan adanya korelasi antar variabel bebas. Model regresi yang baik seharusnya tidak terjadi korelasi di antara variabel independen. Untuk mendeteksi ada atau tidaknya multikolinieritas di dalam model regresi dapat dilihat dari nilai VIF (Variance Inflaction Factor) dan nilai tolerance. Jika tolerance $<0,10$ atau sama dengan nilai VIF $>10$ maka data tersebut menunjukkan adanya multikolinieritas (Ghozali, 2006:92). Hasil pengujian multikolinearitas dapat dilihat pada table berikut :

Tabel 1

Uji Multikolinearitas Coefficients $^{\mathrm{a}}$

\begin{tabular}{|c|c|c|c|c|c|c|c|}
\hline \multirow[t]{2}{*}{ Model } & \multicolumn{2}{|c|}{$\begin{array}{l}\text { Unstandardized } \\
\text { Coefficients }\end{array}$} & \multirow{2}{*}{$\begin{array}{c}\text { Standardize } \\
\mathrm{d} \\
\text { Coefficient } \\
\mathrm{s} \\
\\
\text { Beta } \\
\end{array}$} & \multirow[b]{2}{*}{$\mathrm{t}$} & \multirow[b]{2}{*}{ Sig. } & \multicolumn{2}{|c|}{$\begin{array}{c}\text { Collinearity } \\
\text { Statistics }\end{array}$} \\
\hline & $\mathrm{B}$ & Std. Error & & & & $\begin{array}{c}\text { Toleran } \\
\text { ce }\end{array}$ & VIF \\
\hline (Constant) & 17.592 & 3.762 & & 4.676 & .000 & & \\
\hline TOTKP & .036 & .097 & .037 & .373 & .710 & 1.000 & 1.000 \\
\hline TOTPL & .223 & .090 & .249 & 2.478 & .015 & 1.000 & 1.000 \\
\hline
\end{tabular}

a. Dependent Variable: TOTK.P

Dari table 1 di atas dapat disimpulkan bahwa model regresi layak dipakai dalam penelitian ini, karena syarat untuk tidak terjadi multikolinearitas sudah dipenuhi yaitu nilai tolerance $>0,10$ atau sama dengan nilai $\mathrm{VIF}<10$

\section{c. Heteroskedastisitas}

Uji heteroskedastisitas bertujuan menguji apakah dalam model regrasi terjadi ketidaksamaan variance dari residual satu pengamatan ke pengamatan yang lain. Jika variance dari residual satu pengamatan ke pengamatan lain tetap, maka disebut homoskedastisitas dan jika berbeda disebut heteroskedastisitas. 
Deteksi ada tidaknya heteroskedastisitas dapat dilakukan dengan melihat ada tidaknya pola tertentu pada grafik scatterplot. Heteroskedastisitas terjadi jika ada pola tertentu, seperti titik-titik yang ada yang membentuk pola tertentu yang teratur (bergelombang, melebar kemudian menyempit). Jika tidak ada pola yang jelas, serta titik-titik menyebar di atas dan di bawah angka 0 pada sumbu Y, maka terjadi heteroskedastisitas (Ghozali, 2006:105).

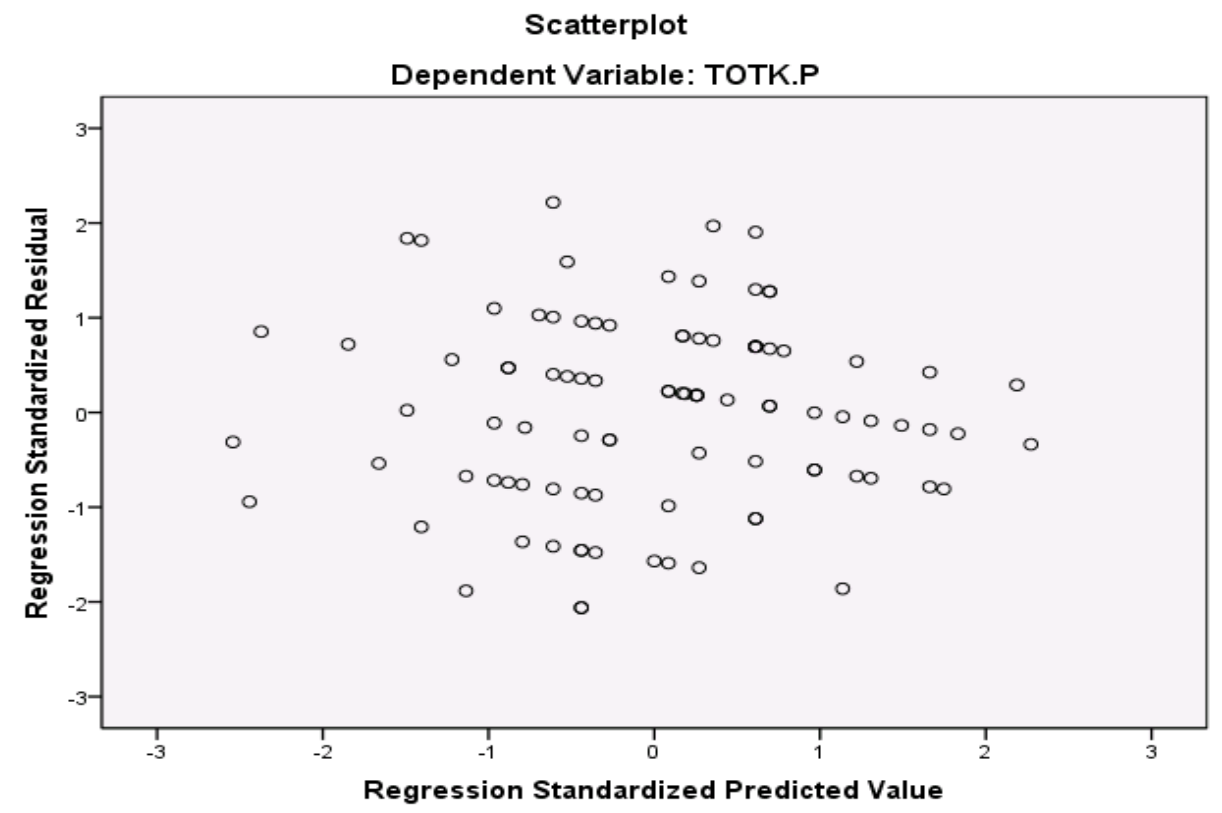

Gambar 3. Uji Heteroskedastisitas

Dari gambar 3 dapat disimpulkan bahwa tidak terjadi heteroskedastisitas dan model regresi layak dipakai.

\section{d. Uji Parsial}

Berdasarkan hasil penelitian yang diperoleh dengan menggunakan analisis regresi berganda dapat diketahui ada tidaknya pengaruh variable independen terhadap variabel dependen. Berikut adalah hasil analisis regresi pengaruh kelengkapan produk dan kualitas pelayanan terhadap keputusan pembelian

Tabel 2. Analisis Regresi pengaruh Kelengkapan Produk dan Kualitas Pelayanan terhadap Keputusan Pembelian 
Coefficients $^{\mathbf{a}}$

\begin{tabular}{|c|c|c|c|c|c|}
\hline \multirow[t]{2}{*}{ Model } & \multicolumn{2}{|c|}{$\begin{array}{c}\text { Unstandardized } \\
\text { Coefficients }\end{array}$} & $\begin{array}{c}\text { Standardized } \\
\text { Coefficients }\end{array}$ & & \\
\hline & B & Std. Error & Beta & $\mathrm{t}$ & Sig. \\
\hline $1 \quad$ (Constant) & 17.592 & 3.762 & & 4.676 & .000 \\
\hline TOTKP & .036 & .097 & .037 & .373 & .710 \\
\hline TOTPL & .223 & .090 & .249 & 2.478 & .015 \\
\hline
\end{tabular}

a. Dependent Variable: TOTK.P

Dari hasil perhitungan analisis regresi dengan program SPSS diperoleh konstanta sebesar 17,592 dan koefisien regresi sebesar 0,036 untuk kelengkapan produk, dan 0,223 untuk kualitas pelayanan. Sehingga dapat diketahui persamaan regresi yang diperoleh sebesar :

$$
\mathrm{Y}=17,592+0,036 \mathrm{X} 1+0,223 \mathrm{X} 2
$$

Persamaan regresi tersebut dapat dijelaskan sebagai berikut :

1. Konstanta sebesar 17,592; artinya jika kelengkapan produk (X1) dan kualitas pelayanan (X2) nilaianya adalah konstan, maka keputusan pembelian (Y) nilainya adalah 17,592.

2. Koefisien regresi variable kelengkapan produk (X1) sebesar 0,036; artinya apabila variable independen lainya nilainya tetap dan kelengkapan produk mengalami kenaikan 1\%, maka keputusan pembelian (Y) akan mengalami kenaikan sebesar 0,036. Koefisien bernilai positif artinya terjadi hubungan positif antara kelengkapan produk dengan keputusan pembelian, semakin naik kelengkapan produk maka semakin meningkat keputusan pembelian.

3. Koefisien regresi variable kualitas pelayanan (X2) sebesar 0,223; artinya apabila variable independen lainya nilainya tetap dan kualitas pelayanan mengalami kenaikan 1\%, maka keputusan pembelian (Y) akan mengalami kenaikan sebesar 0,223 .

Jadi persamaan regresi tersebut menunjukkan bahwa setiap terjadi perubahan pada kelengkapan produk dan kualitas pelayanan akan berpengaruh kepada keputusan pembelian.

Berikut akan diuraikan hasil pengujian hipotesis satu per satu. Untuk menganalisis $t_{\text {hitung }}$ yaitu dengan membandingkan nilai $t_{\text {hitung }}$ dengan $t_{\text {table. }}$ Nilai $\mathrm{t}_{\text {hitung }}$ dapat diperoleh dari hasil analisis regresi. 
Tabel 3. Hasil Uji T

Coefficients $^{\mathrm{a}}$

\begin{tabular}{|c|c|c|c|c|c|}
\hline \multirow[t]{2}{*}{ Model } & \multicolumn{2}{|c|}{$\begin{array}{c}\text { Unstandardized } \\
\text { Coefficients }\end{array}$} & \multirow[t]{2}{*}{$\begin{array}{c}\text { Standardize } \\
\mathrm{d} \\
\text { Coefficient } \\
\text { s }\end{array}$} & \multirow[b]{2}{*}{$\mathrm{t}$} & \multirow[b]{2}{*}{ Sig. } \\
\hline & $\mathrm{B}$ & Std. Error & & & \\
\hline (Constant) & 17.592 & 3.762 & & 4.676 & .000 \\
\hline TOTKP & .036 & .097 & .037 & .373 & .710 \\
\hline TOTPL & .223 & .090 & .249 & 2.478 & .015 \\
\hline
\end{tabular}

a. Dependent Variable: TOTK.P

\section{Pengaruh Kelengkapan Produk terhadap Keputusan Pembelian}

Berdasarkan perhitungan dari hasil analisis regresi pada table 3 dapat diketahui

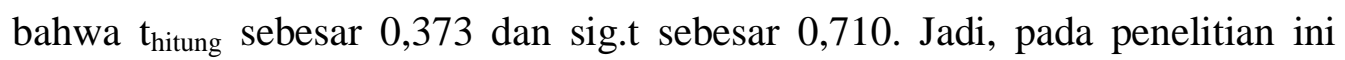
$\mathrm{t}_{\text {hitung }} 0,373$ dengan sig.t $<$ alpha $(0,710>0,10)$. Maka $\mathrm{H} 1$ yang menyatakan diduga terdapat pengaruh kelengkapan produk terhadap keputusan pembelian di Swalayan Adabaru tidak dapat diterima.

\section{Pengaruh Kualitas Pelayanan terhadap Keputusan Pembelian}

Berdasarkan perhitungan dari hasil analisis regresi pada Tabel 4.9 dapat diketahui bahwa nilai $t_{\text {hitung }}$ sebesar 0,249 dan sig.t sebesar 0,015. Jadi, pada penelitian ini $t_{\text {hitung }} 2,478$ dengan sig.t $<$ alpha $(0,015<0,10)$, maka H2 yang menyatakan diduga terdapat pengaruh kualitas pelayanan terhadap keputusan pembelian di Swalayan Ada baru dapat diterima.

\section{Pengaruh Kelengkapan Produk dan Kualitas Pelayanan terhadap Keputusan Pembelian}

Uji F digunakan untuk mengetahui pengaruh secara simultan variable bebas $(\mathrm{X})$ terhadap variable terikat $(\mathrm{Y})$. Nilai $\mathrm{F}_{\text {hitung }}$ dapat diperoleh dari hasil analisis regresi

Tabel 4 Hasil Uji Simultan (Uji F)

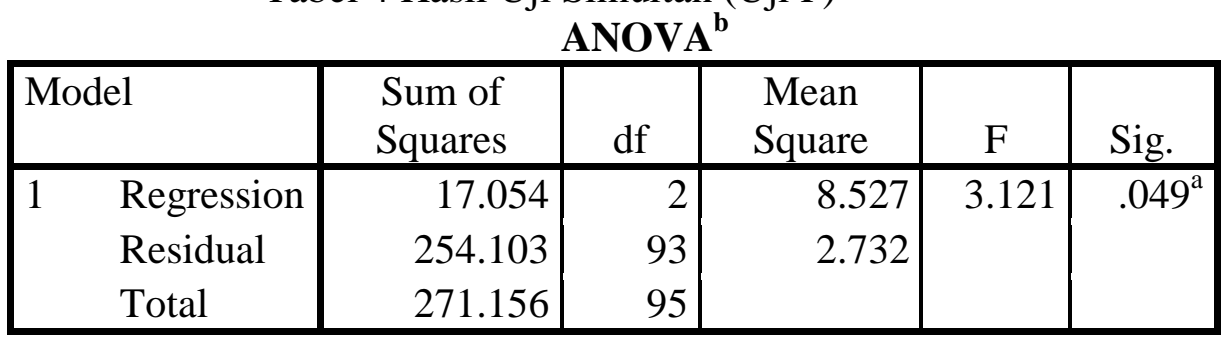

a. Predictors: (Constant), TOTPL, TOTKP

b. Dependent Variable: TOTK.P 
Berdasakan perhitungan dari hasil analisis regresi pada Tabel 4 dapat diketahui bahwa nilai $F_{\text {hitung }}$ sebesar 3,121 dan sig.F sebesar 0,049. Jadi pada penelitian ini $F_{\text {hitung }}$ sig.F < alpha $(0,049<0,10)$. Maka $\mathrm{H} 3$ yang menyatakan bahwa diduga terdapat pengaruh kelengkapan produk dan kualitas pelayanan terhadap keputusan pembelian di Swalayan adabaru secara simultan dapat diterima.

Tabel 5 Hasil $\mathrm{R}^{2}$

Model Summary ${ }^{\mathrm{b}}$

\begin{tabular}{|c|c|c|c|c|}
\hline Model & $\mathrm{R}$ & R Square & $\begin{array}{c}\text { Adjusted R } \\
\text { Square }\end{array}$ & $\begin{array}{l}\text { Std. Error of the } \\
\text { Estimate }\end{array}$ \\
\hline 1 & $.251^{\mathrm{a}}$ & .063 & .043 & 1.653 \\
\hline
\end{tabular}

a. Predictors: (Constant), TOTPL, TOTKP

b. Dependent Variable: TOTK.P

Hasil uji $\mathrm{R}^{2}$ digunakan untuk mengetahui persentase semua variable independen yaitu kelengkapan produk dan kualitas pelayanan terhadap variable independen keputusan pembelian. Berdasarkan table 5 di atas hasil analisis $\mathrm{R}^{2}$ diperoleh 0,063 , yang berarti presentase pengaruh kelengkapan produk dan kualitas pelayanan terhadap keputusan pembelian sebesar $6,3 \%$ dan sisanya sebesar 93,7\% dipengaruhi oleh variable lain yang tidak diteliti.

\section{KESIMPULAN}

Dari hasil analisis dan pembahasan maka dapat dibuat simpulan sebagai berikut:

1. Dari hasil analisis diperoleh $t_{\text {hitung }}$ dengan sig.t $<$ alpha $(0,710>0,10)$, yang berarti bahwa hipotesis 1 yang menyatakan diduga terdapat pengaruh kelengkapan produk terhadap keputusan pembelian di Swalayan Adabaru tidak dapat diterima. Yang berarti kelengkapan produk tidak memiliki pengaruh terhadap keputusan pembelian bagi konsumen di Swalayan Adabaru.

2. Dari hasil analisis diperoleh $t_{\text {hitung }} 2,478$ dengan sig.t $<$ alpha $(0,015<0,10)$, maka $\mathrm{H} 2$ yang menyatakan diduga terdapat pengaruh kualitas pelayanan 
terhadap keputusan pembelian di Swalayan Adabaru dapat diterima. Hal ini berarti bahwa semakin baik kualitas pelayanan yang diberikan oleh pegawai di Swalayan Adabaru akan semakin tinggi tingkat keputusan pembelian.

3. Dari hasil analisis diperoleh $F_{\text {hitung }}$ sig.F $<$ alpha $(0,049<0,10)$. Maka H3 yang menyatakan bahwa diduga terdapat pengaruh kelengkapan produk dan kualitas pelayanan terhadap keputusan pembelian di Swalayan adabaru secara simultan dapat diterima. Hal ini berarti baik semakin tinggi tingkat kelengkapan produk dan semakin tinggi kualitas pelayanan pegawai secara bersama-sama, semakin tinggi tingkat keputusan pembelian.

\section{SARAN}

Dengan memperhatikan simpulan di atas, maka dapat disampaikan saransaran sebagai berikut :

1. Berdasarkan hasil kuesioner penelitian menunjukkan bahwa menurut responden produk yang ada di Swalayan Adabaru kurang bervariasi. Oleh karena itu hendaknya Swalayan adabaru berusaha untuk meningkatkan variasi produk terutama ketersediaan produk secara lengkap baik dalam merek, ukuran dan kualitas.

2. Berdasarkan hasil kuesioner penelitian menunjukkan bahwa responden merasa perhatian individual yang diberikan Swalayan Adabaru kepada pelanggan kurang. Oleh sebab itu, sebaiknya Swalayan Adabaru lebih cepat dalam memberikan pelayanan dan menyelesaikan keluhan pelanggan, serta memberikan rasa aman dan juga pegawai yang ada di Swalayan Adabaru lebih ramah lagi didalam memberikan pelayanan kepada pelanggan, satu contoh dengan memberikan salam ketika dating dan mengucapkan terima kasih ketika pelanggan selesai berbelanja.

3. Bagi peneliti lain masih sangat terbuka peluang untuk melakukan penelitian serupa dan disarankan memilih variable-variabel yang lain yang lebih banyak, sehingga penelitian dapat berkembang dan dapat mengungkap lebih banyak permasalahan yang dapat mempengaruhi keputusan pembelian konsumen dalam membeli produk atau barang yang diinginkan. 


\section{DAFTAR PUSTAKA}

Ahyari, Agus. 2002. Manajemen Produksi, Pengendalian Produksi. Yogyakarta: BPEE.

Engel, James F \& Paul Miniard. 2001. Perilaku Konsumen. Jakarta: Binarupa Aksara.

Gilbert, David. 2003. Retail Marketing Management. New Jersey: PrenticeHall.

Ghozali, Imam. 2006. Aplikasi Analisis Multivariate dengan Program SPSS. Semarang: UNDIP.

Kismono, Gugup. 2001. Pengantar Bisnis. Yogyakarta: BPEE.

Kotler, Philip. 2002. Marketing Management. New Jersey: The Millennium Edition, PrenticeHall International Edition.

Kotler, Philip. 2005. Manajemen Pemasaran. Jakarta: Indeks

Kotler, Philip \& G. Amstrong. 2004. Prinsip-Prinsip Pemasaran. Jakarta: PT. Indeks Kelompok.

Lupiyoadi, Rambat. 2001. Manajemen Pemasaran Jasa: Teori dan Praktik. Jakarta: Salemba Empat.

Ma’ruf, Hendri. 2005. Pemasaran Ritel. Jakarta: Gramedia Pustaka Utama.

Mowen, John C, Michael Minor, Dwi Kartini Yahya. 2002. Perilaku Konsumen Jilid 2 Edisi Kelima. Jakarta: Erlangga.

Payne, Adrian. 2006. The Essence of Services Marketing: Pemasaran Jasa. Terjemahan Tjiptono, Fandy. Yogyakarta: PT. Andi.

Peter, Olson. 2005. Consumer Behaviour \& Marketing Strategy. New York: McGrawHill.

Raharjani, Jeni. 2005. Analisis Faktor-faktor yang Mempengaruhi Keputusan Pemilihan Pasar Swalayan Sebagai Tempat Berbelanja (Studi Kasus Pada Pasar Swalayan di Kawasan Seputar Simpang Lima Semarang). Dalam Jurnal Studi Manajemen \&Organisasi, Vol. 2 No. 1 Hal 1-15.

Rismiati, Catur \& Bondan Suratno.2003. Pemasaran Barang dan Jasa. Jakarta: Konisius.

Santoso, Singgih. 2007. Faktor-faktor yang Mempengaruhi Konsumen untuk Berbelanja di Supermarket Carrefour Yogyakarta. Dalam Jurnal Riset Manajemen \& Bisnis, Vol 2 No. 1 Hal 56-71. 
Schiffman, Kanuk. 2008. Perilaku Konsumen. Edisi 7. Jakarta: PT. Indeks

Setiadi. 2003. Perilaku Konsumen dan Implikasi untuk Strategi dan Penelitian Pemasaran. Jakarta: Kencana Prenada Media Group.

Simamora, Bilson. 2004. Panduan Riset Perilaku Konsumen. Jakarta: Gramedia Pustaka Utama.

Suharsimi, A. 2006. Prosedur Penelitian: Suatu Pendekatan Praktik. Edisi Revisi VI. Jakarta: PT. Rineka Cipta.

Sugiyono. 2009. Metode Penelitian Bisnis. Bandung: Alfabeta.

Swastha, Basu \& Irawan. 2001. Manajemen Pemasaran Modern. Yogyakarta: Liberty Offsett.

Tjiptono, Fandy. 2001. Strategi Pemasaran. Yogyakarta: Andi

Yang, Zhilin dkk. 2004. Measuring Customer Perceived Online Service Quality. Dalam International Journal of Operations and Production Management. Vol. 24 No. 11.

Zainuddin. 2002. Metodologi Penelitian. Surabaya: Airlangga University Press. 